\title{
UNENFORCEABLE TARGET MOVABLE PROPERTY UNDER ENFORCEMENT
}

\author{
David Elisabedashvili * \\ Grigol Robakidze University, Georgia,E-mail: dato_elis@yahoo.com
}

(Received: September 2021; Accepted: November 2021; Published: December 2021)

\begin{abstract}
Nowadays, enforcement is one of the crucial elements of justice. Right to the property is guaranteed by the constitution and therefore exercising property rights is one of the key goals of justice, the latter is implemented through effective and efficient enforcement. The present study is mainly dedicated to the specifics of enforcing property rights. Methods used in the research involve qualitative study, the latter encompasses observation of rules and regulations in national and international practices based on primary and secondary legal and historical sources, including official legal documents, court decisions as first-hand material, as well as derived sources such as various articles, monographs, comments on laws and regulations, etc. The comparative method used in the study is aimed at demonstrating differences and similarities of enforcement rules and procedures in different legal systems, revealing their advantages and disadvantages, while practical examples focus on the identification of gaps to lay the path for better legal solutions. The complex scrutiny of the subject to the present research allows to review it from different angles and suggest legal recommendations to raise the efficiency of the enforcement system and subsequently provide a firm basis for justice.
\end{abstract}

Keywords: Debtor; Seizure; Property; Justice; Creditor.

\section{Introduction}

Enforcing a legal judgment is an integral part of the available court right. "Ubi ius, ibi remedium", which means "where there is a right there is a remedy". This is the process of ensuring compliance with laws, and also the final step for establishing impaired rights. According to the Rec 17/2003 "Enforcement means the putting into effect of judicial decisions, and also other judicial or non-judicial enforceable titles in compliance with the law which compels the defendant to do, to refrain from doing or to pay what has been adjudged". Since justice bears no sense and force without putting it into practice, the importance of justice is directly proportional to the

\footnotetext{
*Corresponding author: David Elisabedashvili.E-mail:dato_elis@yahoo.com
}

Copyright (C) 2021 The Author(s). Published by VGWU Press

This is an Open Access article distributed under the terms of the Creative Commons BY 4.0 license (Creative Commons - Attribution 4.0 International - CC BY 4.0) which permits unrestricted use, distribution, and reproduction in any medium, provided the original author and source are credited.

103 sciendo Journal of Legal Studies Volume 28 Issue 42/2021 
Elisabedashvili, D., (2021)

significance of enforcement. Court decisions would be left alone dusting on bookshelves without the means to execute them. That is why the modern legal world cannot do without the core issue of the present study and the research bears such theoretical and even more practical value today. Among the rights granted by the court property rights are substantial and one of the most vulnerable and fragile rights without proper enforcement. That is why the specifics of exercising property rights are the central milestone to the present research.

In recent decades, enforcement has substantially changed. We face the need to recover the debts in modern society quite often. For example, the removal of tax debt arrears, the repayment of loans with property acquisition purposes, other credits, and so on.

According to the Georgian Enforcement Law, an enforcement officer is authorized to get to the registration place of a debtor or the spot pointed out by a creditor and sequestrate the items there with the aim to sequestrate the movable property not bound to registration. It is supposed that the items investigated on the address are the debtor's belongings, in case if the vice versa is not proofed. In particular, any third party having the right to sequestrated items can apply to the court on the legal boundaries of which the enforcement is carried out and can demand that the property is not sequestrated. Herewith, the presentation of the property list by a debtor is one of the modes of the quest of the above-mentioned property.

Therefore, the difficulties that have arisen in the previous stage, are expected to occur during the enforcement. However, often resolving these issues is beyond the legislation. One of the aspects that need to be considered to protect the balance between debtor's and creditor's rights is the determination of the property that cannot be seized or possibly exempt property. The current edition of the law gives a very general definition of the property that cannot be seized. The legal provision is so vague that it will also be difficult for the court to clarify the conformity of the concrete property with the law. The purpose of the article is to analyze the problem comprehensively, to review similar regulations of developed countries and to offer a completed alternative to the vague provisions of law.

\section{Historical excursion}

In general, during the history of enforcement law development enforcing a legal judgment has always been the „Heel of Achilles“ (Uitdehaag, 2013). There are a variety of reasons for improper enforcement, though the main problem lies in the fact, that in most countries the legislation was out of date and incompatible with constantly changeable and renewable reality and failed to regulate an increased demand on enforcement properly.

"Georgian feudal era law has given us a thorough study of the report that at that time there was an effective mechanism of enforcing a court decision or other jurisdiction

104 Sciendo Journal of Legal Studies Volume 28 Issue 42/2021

ISSN 2457-9017; Online ISSN 2392-7054

Web: publicatii.uvvg.ro/index.php/jls. Pages $103-123$ 
acts. It was certainly an important guarantee of defending enforcement parties' rights. Since 1801, after joining Russia, the sophisticated and efficient legal system of the royal principalities has been replaced by pronounced reactionary and based on inequality legal proceedings. As the result, instead of the previously existing enforcement system, we got completely ineffective enforcement law and a generally ineffective legal system. In terms of the enforcement proceedings, the judicial reform was implemented since 1864 and as a result of this reform, the allocation of a separate field of procedural law should be progressively assessed. However, should be noted, that despite the reform, in fact, the enforcement proceedings were still ineffective. In 1918-1921 years Georgia in fact has not changed the system of civil procedure and, therefore, the law enforcement system. As for the Soviet period, there were less effective enforcement proceedings in Georgia. In addition, it is noteworthy that in general at the legislative level, the procedural rights of the parties were ignored (Chkonia, 2014). The situation changed only in 1997 by the decision of the European Court of Human Rights about the case of Hornsby v. Greece. In particular, the court found that the right to a fair trial guaranteed by Article 6 of the European Convention on Human Rights also applied to enforcement proceedings. According to Article 6 of the Convention - "It would be inconceivable to be described in detail the procedural guarantees for the parties of the dispute under Article $6 \S 1$, in particular- the right of fair, timely and effective trial and at the same time did not envisage enforcement of the court decision" (European Court of Human Rights, 1997). Consequently, it has been repeatedly emphasized that "Enforcement of judgments is an integral part of a "fair trial" under Article 6 of the Convention" (Uitdehaag, 2013). "In relation to subsequent cases discussed by the court it has been determined that regardless of the nature of the enforcement document, it is obligatory for enforcement" (Uitdehaag, 2013).

\section{Main Text}

Despite the fact that the debtor is the one, who has violated the rights of the creditor and the judgments against him/her, as well as enforcement proceedings, $\mathrm{s}(\mathrm{he})$ is entitled to require protection of his/her rights envisaged by the law. Regardless of the quality of contract provision or law violation from the debtor's side nothing can justify impingement of basic rights guaranteed by the legislation. One of the most important factors in the enforcement proceeding is to protect the right of the debtor so that the enforcement process is not a punishment for the debtor despite its repressive nature. In accordance with the Council of Europe's Recommendation, the debtor is required to be provided with the minimum amount of property that is necessary for existence. It is also important to consider creditors' interests in determining the subsistence minimum. The right to live is guaranteed by the constitution and any act that deprives the person of basic and absolute rights is a 
Elisabedashvili, D., (2021)

crime. Enforcement will not be regarded as a crime if it provides proper balance and hierarchy among the rights of creditor and debtor. Therefore, one of the key functions of lawful enforcement is to prevent an imbalance between the rights of the parties. Executive measures should be taken and handled so that the entire process is maintained and the final result is not destructive to any of the parties. The property that cannot be seized is mainly spelled out in the "Law of Georgia on Enforcement Proceedings" (Parliament of Georgia, 1999). However, in some cases, there is no direct list and we have to search for different normative acts and court decisions to get specific answers. Sometimes normative acts do not provide sufficient wording and clarifications on how to apply particular rules and regulations, how to put them into practice, while comments or court practices contain wider interpretations on how the legislative provisions function.

\subsection{State-level interest property}

According to the law, the property is divided into two parts. On the one hand, there is a list of the property which is of a state-level interest and cannot be used as a source of debt recovery. The main principle here is that it is not allowed to get them into private property, because it may involve the state interest in the future. There is a list of such properties are stated in article 21 of "The Law of Georgia on Enforcement Proceedings". The following state property is not liable to privatization by article 4 of "The Law of Georgia on State Property": Mineral resources, water resources, air space, continental shelf, etc. (Parliament of Georgia, 2010). This is the case when the property is clearly defined and we can verify the property that cannot be used as a source of debt payment in accordance with Article 21 (1) of the law. Paragraphs 2 and 3 of the same article are more general, stating that seizure does not apply to the financial collateral and the settlement account of a significant system participant under the "Law of Georgia on Payment Systems and Payment Services" (Parliament of Georgia, 2012). The law gives a clear definition of what might be the subject of financial mortgage and the important system's settlement account. In the first case, these means financial instruments or funds existing on the account, which, in accordance with the law, are used as collateral. What about the second part, it is differentiated a little bit difficult, because we have to define it in three parts, in particular, a) the important system- this is the operating system registered by the Financial Supervisory Agency having three or more participants and considered important in the system of law under Article 4; b) a legal entity, that directly can issue transfer order and is considered as a part of the system according to the system rules may be a part of the system. It can be: Georgian National Bank, Foreign Central Bank, Financial Institution, International Financial Institutions, Payment service providers, Settlement agent, the system operator, the Ministry of Finance of Georgia or its structural unit, State agency or payment system of another country; c)

106 S sciendo Journal of Legal Studies Volume 28 Issue 42/2021 
settlement Account is a unique record of the settlement agent which accounts the funds or financial instruments and through which payments are made.

\subsection{Private property that is not subject to seizure}

Finally, we come to the conclusion that the property which cannot be levied in accordance with article 21 is clear and does not require a lot of work. In the process of enforcement in relation to individuals, Article 45 is particularly important, which states the private property, which is not subject to seizure. Let's discuss this article in detail. In its first paragraph, there is an almost complete list of the assets that cannot be levied. It is mainly about the property that the person needs for elementary living, in order to ensure the minimum livelihood of individuals and his/her dependents. The property includes items necessary for a professional activity, life and household: Four weeks' food, fuel and light treatment or the money to buy them for a debtor and other individuals living with him/her. As well as domestic animals, whose alternative is given by the law, food for them or the required amount of money to buy it. In accordance with paragraph " $v$ ", the payment cannot be made from the targeted assistance. There is no any definition of "targeted assistance" in the "Law of Georgia on Enforcement Proceedings". However, we can see the definition of this term in the N 225/N order of Ministry of Labor, Health and Social Affairs of Georgia" (Minister of Labour, Health, and Social Affairs of Georgia, 2006) On the appointment and issue of Targeted Assistance" which states that targeted social assistance is a monetary allowance relating to the improvement poor families socialeconomic conditions, reduction or prevention the level of the poverty identified by the assessment system. As a paragraph " $z$ ", it's about a vulnerable group whose index is under 57001 points. The subsistence minimum, which is necessary for the life of a person is determined by the Statistics Department and that is the data bailiff's action is based on during the enforcement process. According to May 2018, the subsistence minimum is 177.80 GEL (National statistics office of Georgia, 2018). This is an indicator of monies, which cannot be seized nowadays.

According to Georgian legislation debtor's movable (non-registered) property is subject to seizure and further enforcement. The definition of target property claims that any movable property of the debtor is subject to seizure excluding exceptions (they will be discussed below). It is implied that movables held by the debtor belong to the latter. It is practiced through the following: The Enforcement Officer visits the debtor's location according to the address stated in the letter of enforcement or in the creditor's application without any further confirmation regardless of the position of a host on the location the enforcement officer is entitled to conduct the act of seizure. If during the inventory of items anyone expresses complaint the latter will be noted in the inventory document and the interested party will be given an explanation, that the issues related to the belonging of seized items can be appealed at the court. 
Elisabedashvili, D., (2021)

Unenforceable Target Movable Property Under Enforcement

According to the law, it does not matter where and within whose property the movables are located. If in the letter of enforcement or creditor's application the location is indicated as the residential address of the debtor the movables will be seized anyway and the interested party is to litigate and prove that the debtor does not reside at the location where belongings were seized. When the interested parties initiate a lawsuit they are entitled to require suspension of enforcement on disputable property. If the complainant fails to submit a claim in a timely manner before the seized movables are auctioned, the interested party has the right to sue the debtor to recover the loss, which occurred due to his/her indebtedness.

The act of seizure frequently became subject to legal disputes, when the interested parties applied to the court to exercise their property rights. One of the cases reached the Supreme Court and all the seized movables were expelled from the document of seizure. According to the Supreme Court, the owner of the immovable property where the seized items had been found was declared the owner of the disputed movable property (The Supreme Court of Georgia Decision №sb-26-24-2013, Tbilisi, 10 July 2013). On the basis of Article 151 of the Civil Code, the court adjudged that the attribute is a movable item which might not be the part of the principal immovable property, but is intended to serve this property, is related to the latter for common household purposes, therefore some movables are in physical connection with the immovable property and it is a well-established point of view that such items are regarded as attributes. According to the abovementioned provision, the capability to service the principal immovable property is the main feature of an attribute and the owner of the principal property will be considered the owner of an attribute (movable property) unless proved otherwise.

The furniture and domestic appliances are intended to service the house (apartment) and are connected to it for common household purposes. The presumptions pursuant to Articles 151 and 158 of the Civil Code served as the vital legal grounds for the final award in favor of a plaintiff and satisfaction of the claim. Such considerations of the Supreme Court are in full compliance with the well-established uniform court practice.

As we can observe the ambiguities in the identification process of non-registered movables are evident. Interpretation of the law does not coincide with the court practice and therefore does not allow to eliminate collisions, create and exercise uniform enforcement practice.

The enforcement system is considered an integral and quite developed part of justice. Issues of enforceable property in European or US / Canada countries are different from Georgian law and are more detailed. Under the Georgian legislation, the property which cannot be used as a source for debt recovery is separately allocated and explained, what it might imply, however, if we look at the same legislative 
regulation of different countries, we'll see that, in some cases, compared to Georgian legislation it is defined more precisely.

For instance, In New York, certain amounts and types of funds are protected from being frozen in a bank account in reference to the collection of private debts. In 2008, the New York state legislature found that in some instances, creditors were pursuing funds that were legally exempt from freezing and levying. In order to stop these illegal account seizures, the New York Exempt Income Protection Act (EIPA) was enacted. Under EIPA, if a creditor attempts to freeze a bank account belonging to the debtor, the first $\$ 2100$ is protected. To be more specified, if a person has savings, it can be seized only above S2100. At this time the debtor is insured to pay unforeseen costs. According to the same legislation, the weekly exemption amount is $\$ 262.50$ (Law Office of Simon Goldenberg, 2015), it's about $1050 \$$ per month. In addition, if we calculate national currency, it will be 2730 GEL, while unfortunately established minimum amount of May 2018 by the Georgian legislation is only $177.80 \mathrm{Gel}$. Of course, it is important to consider the economic and financial condition of the country, but I think the difference is still very high.

Differing from the Georgian Enforcement Law, article 728 of the new Code of Civil Procedures of Luxembourg more clearly defines the types of immovable properties not the subject to seizure. In particular, beds needed by the judgment debtor and his family, clothes and linen for their personal needs, as well as the furniture needed to store them in, a washing machine and iron, appliances needed to heat the family home, tables and chairs enabling the family to have a meal together, as well as the dinnerware and household utensils that are absolutely necessary for the family, a piece of furniture to store the dinnerware and household utensils, a cooker, a refrigerator, a lighting fixture per inhabited room, items needed by disabled members of the family, items intended for use by children who are dependent on those who live under the same roof, pets, the items and products needed for personal hygiene and for keeping the rooms clean and tidy, the tools needed for maintaining the garden, to the exclusion of luxury furniture and items.

In Canada, Quebec the following property is protected and cannot be seized during a seizure of your movable property: the food, fuel and clothing needed for the life of you and your family; the furniture in your main residence needed for the daily life of your family and any personal belongings you choose to retain, up to a market value of $\$ 7,000$; work instruments needed for the exercise of your profession; objects needed to alleviate a disability or care for the illness of a family member; pets; medals and other similar decorations; objects used for family worship.

Polish Legislation stipulates opposite rule. In particular, no more than the movable property required to satisfy the claim and costs of enforcement should be seized besides the debtor's following movable property: is in his/her possession, or in the possession of the creditor, who has provided for the execution against it, is in 
Elisabedashvili, D., (2021)

Unenforceable Target Movable Property Under Enforcement

possession of a third party, but only if the third party consents to it being seized or acknowledges that it is the property of the debtor and in cases specified in provisions of law. In the case of enforcement against maintenance obligations, the judicial officer may also seize the movable property which is in possession of a person residing together with the debtor, without the consent of that person, unless such person provides proof that the movable property belongs to him/her.

If we make a comparison between Georgian and the above-mentioned Countries' enforcement provisions, we clearly go to the conclusion that the Georgian Enforcement Law needs to be more clear regarding which type of movable assets can't be subject to seizure and enforcement procedures.

\subsection{Time Deposit}

In the context discussed above, it is also important to mention time deposits. Since they are often confused with the private property of the debtor, while the legal and contractual regulations on deposits bear a completely different nature.

The enforcement might be directed at incomes and monies in the accounts of the debtor. The income of a debtor encompasses salary, scholarship, dividend and they are subject to enforcement in a special way.

As for the monies accrued in the debtor's accounts, they might be used for enforcement purposes if they don't fall within the exception discussed below.

In practice when the enforcement officer is informed that monies are located in the debtor's account(s) which is sufficient to satisfy the creditor's financial claim completely or partially, the officer will send an encashment task in accordance to which the transaction will be conducted, the proper amount of monies will be detained and transferred to cover the indebtedness.

This rule does not apply to the cases when the debtor has a time deposit placed in an account. According to the Civil Code of Georgia when monies are placed on a time deposit account the credit institution obtains property rights on such financial resources and is obliged to return them in the same currency at the end of the deposit term. The latter means that the credit institution becomes the owner of the deposited monies (Zambakhidze, 2000). Therefore it is implied that these financial resources are not located in the debtor's account, but the debtor only has the right upon stipulated conditions to claim the refund of such monies with the accrued interest. That is why the abovementioned case represents an exception from the general rule of enforcement related to movable property. Therefore, its discussion in the present study is only for the purposes of comparison not for the in-depth analysis.

\subsection{Property of socially vulnerable people}

"Target assistance provided by the state, property of a family member registered in the unified database of socially unprotected families are not subject to seizure,

110 Sciendo Journal of Legal Studies Volume 28 Issue 42/2021 
besides a provision of security, the socio-economic indicator of which is lower than the Georgian government has prescribed" (Parliament of Georgia, 1999). This part is very well organized in the enforcement proceedings. Upon commencement of enforcement proceedings, the program, where a bailiff works, automatically checks the debtor in the social agency and if it is less than the score that is prescribed by the Government Decree, there is made an appropriate designation, that the debtor is socially vulnerable. This means that the property of the debtor is not subject to seizure and therefore the bailiff does not find and seizure the property.

As for social assistance, in this case, other countries' laws are quite strict too. In particular, by the New York state legislation If the debtor's income exceeds the protected limits on earned income, then $90 \%$ of the gross is exempt (or $75 \%$ of the disposable income is exempt, whichever is higher).

According to the same law, the types of funds that are exempt from debt collection are:

1.) Social Security; 2.) Disability Benefits; 3.) Alimony or child support; 4.) Any form of public assistance; (e.g. welfare) 5.) Any income earned while on public assistance; 6.) Workers compensation; 7.) Supplemental Security Insurance; 8.) Most public or private pensions; 9.) Retirement accounts (401k, IRA); 10.) Unemployment Insurance and 11.) Veterans benefits (VA) (Law Office of Simon Goldenberg, 2015).

\subsection{Subsistence Minimum}

On the one hand, it is noteworthy to balance the effective means of enforcing the decision, and on the other hand, to take into account the interests of the debtor in the dignity and security part. It is about all the aspects of the enforcement of the decision, especially the income levy, upon which the debtor is dependent on, in particular food, shelter, clothes and other needs.

This has important implications for values of social justice and equality. It is well established that single-mother-headed households are more likely to live at the poverty line than other families (Law Reform Commission of Nova Scotia, 2013).

According to the Georgian legislation, exempt from levy concerns less income than subsistence minimum. If the bailiff is aware of such income, it is possible to identify it. Even the determination of subsistence minimum may arise lacuna. In particular, upon the commencement of the enforcement proceedings, the balance on the bank account of the debtor is frozen. In this case, the freezing process is carried out on the full amount specified by the enforcement proceedings, therefore the subsistence minimum cannot be separated. After this procedure, if the debtor is limited to use the subsistence minimum amount provided by the law, (s)he will be able to access her/his account only if (s)he will provide information to the bailiff on her/his financial circumstances, from where the bailiff will be able to access the subsistence 
Elisabedashvili, D., (2021)

minimum for the debtor. In other cases, the whole income of the debtor will be paid for enforcement without taking into account the subsistence minimum. It happens because according to today's system, the bailiff has no possibility to act otherwise. However, the debtor is also able to protect her/his interests.

The subsistence minimum is defined by the Department of Statistics. However, within the enforcement process, during the concrete proceeding, the debtor may require that the subsistence minimum remains not only for him but for the family members living with him too. (For example, spouse and two adult children). The legislation does not clarify who are the debtor's dependents, who bear the burden of proof in a particular case.

In practice: When a debtor demands that the enforcement not to carry out on a subsistence minimum that is necessary for a four-member family, the bailiff asks him to provide a document confirming the presence of family members on the debtor's dependency. A similar document i.e. determining a fact can be issued by the court, but the actual term of the proceeding exceeds one month.

In this case, we face a shortcoming. The subsistence minimum in its essence means the amount of money to create the minimum conditions that are necessary for living because without this amount of money it is possible to end fatally the life of a debtor or debtor's dependents. It should also be taken into account that more income than subsistence minimum is subject to enforcement and if a family member of a debtor is considered to be dependent, but (s)he can exist independently, it will cause damage to the creditor. In this case, it is better for enforcement representatives to be more effective.

In practice in such a situation, the way out is as follows: The bailiff asks the debtor to provide a document confirming who is registered with him in an apartment. (This episode also requires consideration because the registering institution is no longer active and if someone is registered at a particular address it does not mean that he lives there. That's why a bailiff shall suddenly visit the debtor during a non-working time and make a record. Also questioning chair of the building, and/or oblige the Ministry of Internal Affairs to inquire about the people residing at a particular address. Hereby we can only determine who lives with the debtor, however, it automatically does not confirm that it is being dependent. The most common form of income is labor remuneration of labor. The bailiff may oblige the debtor to provide a notice that people living with him do not work at the present time and have not worked for the last period. Only after it, there is a relatively comprehensive information, whether or not his family members are dependent on the debtor. However, this information is not perfect and maybe misleading for the bailiff because a family member may not be a person in labor, but receive income by a noncash payment for a certain job. 
As Buckwold and Cuming observe, "the purpose of modern exemption law is not only to enable the judgment debtor and his or her family to maintain a subsistence standard of living, but to permit them to function as healthy, productive and contributing members of society" (Buckwold \& Cuming, 2005). A minimum threshold of income exempt from seizure should ensure that the debtor has sufficient funds to maintain an adequate standard of living. In particular, it should ensure that low-income debtors are not reduced to an unreasonable living situation, and further marginalized, by virtue of a judgment debt.

There are three main measurements of low income - or 'poverty lines' - used in Canadian statistics: The Low-Income Cutoffs (LICO), Low Income Measurement (LIM), and Market Basket Measure (MBM) The following sections assess each on the basis of their relative fairness, effectiveness and practicality as a measurement for determining a threshold amount, below which no income should be subject to seizure.

The Low Income Cut Off (LICO) is an income threshold calculated by Statistics Canada which indicates the minimum level of income that an individual or family will need to afford a reasonable standard of living in Canada today (Raphael, 2007). The LICO measurement indicates at what income level a family will be spending more of its income on necessities such as food, shelter, and clothing, than a large majority of Canadian families.

The Low Income Measurement (LIM) is another income threshold published by Statistics Canada. The LIM is given as a fixed percentage (50\%) of median adjusted family income (Government of Canada, 2015). The MBM threshold amount represents the cost of a 'basket' of essential goods and services. The MBM is meant to provide more of an absolute or concrete indication of living conditions than either the LICO or the LIM. These goods and services include food, shelter, clothing, footwear, transportation, personal care, household needs, furniture, basic telephone service, school supplies and modest levels of reading material, recreation and entertainment. The cost of the basket of goods and services is assessed separately for each province and different regions within the province.

The Basic Needs Poverty Line defines poverty not in terms of inequality but in terms of insufficiency. To this end, the measure itemizes and costs basic necessities without which a family can be said to have reached an unacceptable level of deprivation. While the methodology is similar to calculating the MBM threshold amount, the basic needs included are far less extensive than those considered by the MBM measure. For example, the 2006 Basic Needs Poverty Line for a family of four was $\$ 22,852$, before tax. The MBM for Halifax, by contrast, was $\$ 29,073$ net of taxes, payroll deductions, child care, child and spousal support, medical expenses and health insurance premiums. The philosophy behind the Basic Needs Line is that poverty is a condition of lacking the most basic needs - food, clothing, shelter, and 
Elisabedashvili, D., (2021)

household essentials.64 Unsurprisingly, there are far fewer people living in poverty defined by the Basic Needs Line than by the LICO or MBM measures.65 The Basic Needs Line is not intended to reflect a reasonable standard of living, or reflect considerations of social inclusion.

The U.S. Federal Consumer Credit Protection Act provides a maximum level of income that may be seized in the event of garnishment of wages.70 Weekly garnishments may not exceed the minimum of $25 \%$ of an employee's disposable earnings.

Approaches to the minimum income threshold vary widely throughout Canada. Wages are not subject to garnishment at all in New Brunswick. In Ontario, there is no minimum income threshold amount.75 In Alberta, 50\% of net income above a minimum income exemption is subject to seizure. The minimum floor is $\$ 800$ per month, plus $\$ 200$ per dependent to a maximum of \$2400 (Law Reform Commission of Nova Scotia, 2013).

The Income Tax Act provides that a dependent is "a person who at any time in the year is dependent on the individual for support and is the child or grandchild of the individual or of the individual's spouse or common-law partner" (Government of Canada, 1985).

As we see, ten years ago, Canada was still paying great attention to determining the subsistence minimum and it is so flexible and voluminous that, according to the reality of Georgia, it can be considered a luxury. To sum up, the solution is still up to the bailiff. In this case, it is necessary to determine which actions can be more damaging and can only be decided afterwards.

\section{Minimum property to ensure the minimum livelihood of the debtor 4.1. Shortcomings of Georgian legislation}

There is an almost well-established list of property that cannot be seized in "Law of Georgia on Enforcement Proceedings". However, we often encounter shortcomings in practice during the realization of these norms. It means that there is a defined property in theory, but it is impossible to perform accurately in practice certain norms because of lack of concrete. Consequently, more accuracy is needed to ensure that the bailiff does not have to make a decision on the assumption level in the immediate process of enforcement proceedings.

"Law of Georgia on Enforcement Proceedings" article 45 paragraph 1 "a" states that personal or family items, which are necessary for a debtor's professional activity, life and household cannot be seized. According to the fact that there is no precise definition of property, it is clear that there is no specific list that determines what could be the items or how much should it cost to be considered as a personal or family property, which are necessary for debtor's professional activity, life and household. There is almost the same definition in paragraph 1 "e", in particular, 
exemption from debt collection is the items that are necessary debtor's physical, mental, or other work. What could be considered of these items for law purposes? How to identify movable property while seizure? As we all know when the bailiff goes to the debtor's residence for description and seizure of the property, (s)he is entitled to inspect each room. If it turns out that the debtor is a professional or street musician, works in the band, or plays the guitar and teaches apprentices, it means that the guitar is a personal, professional item and cannot be seized. If there is an expensive guitar, which does cost more than 15000 can it be seized? What happens if the bailiff finds 4-5 different value guitars? How to behave a bailiff to be his/her action legal and fair too? According to the fact that the total value of these instruments may exceed $50000 \mathrm{GEL}$, it is possible to enforce the obligation by selling even one of them. It is also interesting how to determine whether the item is important for professional activity or physical/ mental work. If the debtor's profession is specific, how to understand which items are necessary? How can the debtor convince the bailiff that (s)he needs it for his/her income? For instance, if the debtor has a car and from time to time it is used as a taxi, how to prove that it is the source of income? What if the debtor works in addition too?

In accordance with Georgian legislation cannot be seized four weeks' food, fuel and light treatment or the money to buy them for a debtor and other individuals living with $\mathrm{him} / \mathrm{her}$ if there is no reserve or other remedy to buy them.

There is a lack of concretization too. How to define this property while the enforcement process? We have three kinds of legibility in this paragraph: 1. Why are the family and other individuals living with him/her separated? Does it mean that the family members still have to be considered regardless of living with the debtor? Or the fact of living together is important? 2. Who could be individuals living with a debtor or how to establish this fact? 3. How to calculate what amount of food, fuel and light will be required for the debtor and other people during the four weeks? Or what amount of money is necessary to buy them?

The property that cannot be seized seems to be clearer according to Article 45 paragraph "g" of the "Law of Georgia on Enforcement Proceedings". In particular," limited number of sheep and goats,), also 1 milk cow, or the debtor's choice of two pigs, sheep or goat if they are necessary for the debtor, his/her family or the people living with him/her, as well as three months' reserve of straw or livestock feed. If there is no any reserve and their purchase is not provided in a different way- a required amount of money to buy them". Apparently, it is designed to prevent the sale of the debtor's property in a way, that (s)he was no longer able to keep himself/herself. However, the list of animals deprives a debtor of the right to choose which of them (s)he would like to, that's why according to the equivalent value of the animal there should be a choice. For instance: if the debtor has a buffalo (this is quite common species in Georgia) turns out that it can be seized full amount of the 
Elisabedashvili, D., (2021)

animals and according to this paragraph a bailiff is not entitled to allow the debtor to have even a single one for keep himself/herself. This norm is mainly useful in the villages and that's why I think such issues are very important to be considered. As for the amount of predetermined term, this also causes a problem and makes a debtor dependent on the bailiff's goodwill. If we decide to fill this paragraph from the previous one, face the trouble of quantity.

As we see there is mainly one type of problem, which is also present in one more paragraph. It states that "agriculture tools, cattle, fertilizer and agricultural products as far as they are needful to keep a debtor, working in agriculture, his/her family, hired workers or the same or similar products of further farm working until the future harvest. This is also very general content and depends on the bailiff's goodwill. However, in this case (s)he may also be powerless to identify the record of the law with the property.

\subsection{Examples of the developed countries}

Interestingly, what different regulations does the legislation mentioned above have about the property that cannot be seized. So the following kinds of personal property are exempt from debt collection: Household goods, like furniture, clothing, and appliances; Medical equipment, such as a wheelchair; One television, one radio, one computer and one cell phone; Personal items like jewelry and art, not exceeding $\$ 1,000$ in value; Items that you need for work, "tools of the trade," not exceeding $\$ 3,000$ in value; $\$ 1,000$ in personal property or cash (The Neighborhood Economic Development Advocacy, 2017).

It is noteworthy, that unlike the Georgian law this one is more concreted the list and identity of the items, which cannot be seized. Even the fact, that wheelchair is exempt from debt collection shows us the purpose of the law not to become enforcement process punishment for the debtor.

Although, despite the list of items, their number is defined, in contrast to the Georgian legislation, where if we consider the law provided the specific property is exempt from debt collection there is no identified number and if a computer is a personal item, it cannot be seized despite the quantity.

As for the items that you need for work, it is true that according to both New York and Georgian legislation, they are included in the list of properties that cannot be paid off, however, unlike the Georgian Regulation, there is a set value that should not exceed the value of these items.

There are different regulations with respect to such matters in the USA, however, the fundamental principles are mainly the same. For example, let's consider New Mexico law where are several categories of exemptions: 1 . exemptions of a type of property, up to a specified value; 2 . exemptions of a type of property, regardless of value, and 3. "wildcard" exemptions that can be applied to any property.

116 S sciendo Journal of Legal Studies Volume 28 Issue 42/2021

ISSN 2457-9017; Online ISSN 2392-7054.

Web: publicatii.uvvg.ro/index.php/jls. Pages $103-123$ 
The first kind of exemption protects the value of your ownership in a particular item or type of property, but only up to a set dollar limit. For example, The New Mexico state exemptions allow you to keep $\$ 4,000$ of equity in a motor vehicle. If you were subject to collection, you could keep your car if it was worth $\$ 4,000$ or less. Even if the property is worth more than the dollar limit of the exemption amount, you can keep the property if selling it would not raise enough money both to pay what you still owe on it and to give you the full value of your exemption. For instance: You own a car worth $\$ 20,000$ but still owe $\$ 16,000$ on it. Selling it would raise $\$ 16,000$ for the lender and $\$ 4,000$ for you, thanks to your New Mexico exemption. Since there would be nothing left over to pay your creditors, the creditor wouldn't take the car. Instead, you would be allowed to keep it as long as you are and remain -current on your payments. However, if your equity in the property exceeds the dollar amount of the exemption, the creditor or trustee may sell the property to raise money. A creditor would return your exemption amount to you, plus any money left over from the sale after costs are deducted and the judgment is paid.

Another type of exemption allows you to keep the specified property, regardless of its value. For instance, a given state's exemptions might allow you to keep a refrigerator, freezer, microwave, stove, sewing machine, and carpets with no limit on their value.

Some states provide a general-purpose exemption called a "wildcard" exemption. This exemption gives you a dollar amount that you can apply to any type of property. This is like the wildcard in poker, which you can use as any card you want. The same principle applies here. You can apply the wildcard exemption to property that would not otherwise be exempt. For example: Suppose you own a $\$ 3,000$ boat in a state that doesn't exempt boats but does have a wildcard of $\$ 5,000$. You can take $\$ 3,000$ of the wildcard and apply it to the boat, which means the boat will now be considered exempt. And, if you have other nonexempt property, you can apply the remaining $\$ 2,000$ to that property.

Or, you can use a wildcard exemption to increase an existing exemption, for instance: If you have $\$ 5,000$ worth of equity in your car but your state only allows you to exempt $\$ 1,500$ of its value, you will likely lose the car. However, if your state has a $\$ 5,000$ wildcard exemption, you could use the $\$ 1,500$ motor vehicle exemption and $\$ 3,500$ of the wildcard exemption to exempt your car entirely. And you'd still have $\$ 1,500$ of the wildcard exemption to use on other nonexempt property.

In most states, you cannot request a claim of exemption to protect your wages if your debt was for necessities, such as rent or mortgage, food, utilities, or clothing. The law says that you should pay for your necessities, even if you suffer hardship in doing so (Reiter).

England legislation more generally refers to the property which cannot be seized. However, in this case, the bailiff (An appropriate officer) has a right to determine 
Elisabedashvili, D., (2021)

this property can be seized or not. An appropriate officer may seize realizable property under section $47 \mathrm{C}$ if the appropriate officer has reasonable grounds for suspecting that the property which belongs to a defendant may otherwise be made unavailable for satisfying any confiscation order that has been made or maybe made against that person, or that the value of the property may otherwise be diminished as a result of the conduct by any person. However, the appropriate officer may not seize under section 47C: "cash", which means notes and coins in any currency, postal orders, a cheque of any kind (including traveler's cheque), bankers' drafts, bearer bonds and bearer shares. or "exempt property", which means such tools, books, vehicles and other items of equipment as are necessary to the defendant for use personally in their employment, business or vocation.

It also includes such clothing, bed, furniture, household equipment, provisions or other things as are necessary for satisfying the basic domestic needs of the defendant and their family (Strategic Centre for Organised Crime, 2015). In addition following items are free from seizure too: Motor vehicles or other goods subject to hire purchase; Perishable goods; Tools of the trade up to £200; Any goods in the hands of a Receiver appointed by a court and Debtor's clothes and essential household furniture (The MyLawyer Legal Team).

Unlike these countries, there are different regulations in Australia. The bailiff can seize personal property such as money, furniture, a TV or radio, electrical appliances or a car, as well as 'choses in action' such as cheque, promissory notes and such like. The property seized must belong to the debtor. Anything on hire purchase, anything rented (for example a TV) and anything belonging to anyone else, such as the debtor's spouse or other relatives, cannot be taken.

When executing a warrant of execution issued out of the Magistrates Court the bailiff cannot take any clothes or bedding, even if they belong to the debtor, if they are being used by the debtor or a member of the debtor's family. Nor can the bailiff take the debtor's tools or implements used by the debtor in his or her trade up to a value of $\$ 3000$. A bailiff must wait 7 days from the date of seizure before offering the property for sale. If the effect of taking the goods would be to deprive the debtor, or any essential requirements of living for the maintenance of health, the court may order that they be restored to the debtor (Hobart Community Legal Service Inc).

\section{Resume}

It is written in the Georgian legislation that the dispute about releasing of property from seizure can be examined in the court (Parliament of Georgia, 1999). It turns out though that the debtor's interest is protected despite the article of the law mentioned above being vague. It means that if this clause included the property that has been seized, the debtor has the right to discuss this issue by the court and achieve success. Although if we consider the terms of the court, it would be much better to define this

118 Sciendo Journal of Legal Studies Volume 28 Issue 42/2021 
paragraph clearer rather than wait for the result of the court, because if the dispute is about food products, the result will be quite poor despite a court decision.

Numerous regulations have been enacted to protect entities on both sides of the debt relationship, and when the due date for payment is passed, effective and ethical conflict resolution often amounts to a careful balancing act between the rights of the creditor, and the rights of the debtor. An effective judicial system is crucial for the development and optimal performance of the market. For instance, Posner argues that lenders (and creditors in general) may assume unjustified risks. The legal enforcement systems are structured with both positive and negative incentives to protect the substantive and procedural rights of the parties involved. Certain assets of the debtor, as well as earnings up to a certain amount, are exempt from attachment and seizure. These exemptions can be explained mostly by reference to the debtor's fundamental rights as guaranteed in the Constitution, although the Constitution does not, of course, prescribe them in any detail. Certain limitations on the rights of the creditor are important for the maintenance of humanity, but also economic reasons, as they create an incentive for creditors better to control and monitor their debtors from the outset and thereby avoid over-indebtedness.

The European Union provides an interesting example of the utility of an effective and fair form of enforcement proceeding. As an area of freedom, security and justice in which the fundamental freedoms must be guaranteed. The European enforcement process includes many measures, derived from public, private, and procedural law. While the enforcement mechanism has helped to achieve the gradual consolidation of the Single Market, national borders often continue to represent a barrier behind which a debtor can take refuge, and sometimes frustrate the creditor's right (Perez Ragone, 2014).

As the Council of Europe's recommendation enacts and practice shows it is inevitable to allow the debtor to leave the minimum property for maintenance. This property is necessary to be thoroughly checked out and calculated exactly for keeping himself/herself because the enforcement proceeding is working on behalf of a creditor's interests. Accordingly, if the property which cannot be levied is not limited, it can cause his/her harm. The clause about the property that cannot be seized is envisaged because of the debtor's minimum conditions for existence. Otherwise, the balance between the rights of the creditor and the rights of the debtor will not be protected. It is Inadmissible to be this regulation so vaguely formulated, that a debtor could take refuge or frustrate the creditor's right. However, the vagueness can be harmful to a debtor's interests too. For example, if the four weeks' food for a debtor and people living with him/her determined by a bailiff or the three months' reserve of straw or livestock feed elected by a debtor are not enough.

According to the shortcomings discussed above, there was an example about the guitar which was necessary for the debtor's profession or the activity that (s)he gets 
Elisabedashvili, D., (2021)

Unenforceable Target Movable Property Under Enforcement

income from. As we see this is the property that cannot be seized, but there is no rule about the number of such items. It means that according to the law if the property does fit the list of the paragraph, it cannot be seized regardless of the number and if the debtor has 4-5 such items, none of them can be seized. It is impossible to keep a balance because the debtor has an opportunity to continue the professional or physical/mental activity by using one of the instruments while others can be sold. This is a chance to get a debtor much more benefits than it's conceded by the law.

\section{Conclusions}

Goals of enforcement cannot be achieved without clear identification of target property. Defining classification criteria is the most important part of the entire enforcement procedure to which movable property is a subject. The study shows and underlines the vital importance of a proper legislative base to ensure correct practice and avoid gaps, collisions and ambiguities. Since jurisprudence is not a precise science no universal remedy or formula can be invented, that is the reason why analyzing different practices and experiences is so crucial. But the latter will not be fruitful or useful without proper legal regulations leaving as small loopholes as possible for misinterpretation. Such an approach helps to keep a balance between the rights of debtor and creditor, to make enforcement procedure more target-oriented, create less unnecessary pressure, avoid mistakes, rule out the dependence of enforcement relevance on bailiff's goodwill, which can be achieved only through detailed and accurate legal provisions. The rules which involve fewer puzzles and more direct legislative solutions contain fewer risks to jeopardize the legitimacy of the entire process.

Since there are no road signs or traffic lights to regulate the enforcement process, words bear the most importance, as well as their context. That's why below it is recommended to adjust the wording of laws and regulations to reality through the analysis of the overall context, to make sure the legislator and the enforcer are on the same page so that the goals and objectives of enforcement regulations are finally achieved through a due balance of the parties' rights and compliance to the general principles of justice. To archive his goal and solve above mentioned legislative and practical problems in Georgian enforcement I strongly recommend the following legislative amendments as described in the following recommendations.

\section{Recommendations}

The world's leading countries have been continuously improving the norms of justice including the regulations related to the enforcement rules. We have repeatedly pointed out that there are many recommendations about it, got a few examples of countries, and eventually agreed on the following: In order to make a careful balance between the rights of the creditor and the rights of the debtor, there should be fully 
determined the property that cannot be seized. It is better to be formulated article 45 as follows: It cannot be levied (seized): clause 1. Debtor's income is under the subsistence minimum considering how many people are his/her dependents. (Department of Statistics of Georgia establishes the subsistence minimum for one person, two, three, etc.), as for what could be an income, they are wages, pensions, targeted assistance, etc.); 2. Debtor's any property under the 57001 points (According to today's edition property of the people under this amount of scores cannot be seized. It turns out that this is the minimum property that is necessary for a person's basic needs. So we can take the National statistics office appraisal for a model and a bailiff will have an opportunity to behave in accordance with it or 2.2. Determine the average value of the debtor's basic life of consumer goods, inventory, equipment and other items and let the debtor possibly choose the property under this value by himself/herself. 3 . In spite of the amount, the one-time assistance provided by the state to which the debtor should be treated. (it is also possible to get the nomenclature and get other similar assistance in it in case of its existence).

This is a modern standard norm, which is completely understandable and definable for enforcement parties, as well as the bailiff and thus it will be possible to protect creditors' and debtors' rights.

The institute of enforcement is meant to satisfy the creditor at the expense of the debtor's interests and nothing can be done about it. It always bears in itself repressive measures against the debtor in the creditor's favor. However clear, unambiguous, gap-free regulations based upon the equality of rights will make the process of justice implementation less painful more balanced, trustworthy and reliable. It might minimize the probability of mistakes and reduce possible risks, eliminating threats to violating the basic rights of the parties. Law is not an exact science, there are no universal formulas, that is why enforcement procedures need constant revision and updates to make sure nothing can illegitimately tip the scales of justice.

\section{Acknowledgments}

The author thanks the anonymous reviewers and editor for their valuable contribution.

\section{Funding}

This research received no specific grant from any funding agency in the public, commercial, or not - for - profit sectors.

\section{Author Contributions}

The entire article was written by David Elisabedashvili.

\section{Disclosure Statement}

The authors have not any competing financial, professional, or personal interests from other parties. 
Elisabedashvili, D., (2021)

\section{References}

1. Alvaro, P. R., (2014). International Association of Procedural Law Seoul Conference 2014, "Session 4: Constitution, Fundamental Rights and Law of Enforcement; 4.2 The conflict between The Fundamental Rights of the Creditor and the Debtor", online: https://www.researchgate.net/profile/Alvaro_Ragone/publication/295861155_The_Conflict s between the Fundamental_Rights_of the _Creditor_and the Debtor/links/56 cfocb808ae b52500c9014b/The-Conflicts-between-the-Fundamental-Rights-of-the-Creditor-and-the-

Debtor.pdf .

2. Council of Europe Committee of Ministers, Recommendation Rec, (2003). 17 of the Committee of Ministers to member states on enforcement.

3. Criminal Finances Team, Strategic Centre for Organised Crime, (2015) "Draft code of practice issued under section 47S of the proceeds of crime act 2002 (Search, Seizure and Detention of Property (England and Wales).

4. Government of Canada, (2015). Low-income measures, online: http://www.statcan.gc.ca/pub/75f0002m/2009002/s3-eng.htm, R.S.C. 1985 c.1 ( $5^{\text {th }} 122$ up.).

5. Hobart Community Legal Service Inc. online:http://www.hobartlegal.org.au/tasmanianlaw-handbook/consumers-money-and-debts/debt/bailiff-powers/seizure,

https://www.hobartlegal.org.au/.

6. Government of Canada, (1985). Income Tax Act, online: http:/lawslois.justice.gc.ca/eng/acts/I-3.3/FullText.html, s 118(6)(a).

7. Justice and Law \#2(41)'14, 2014, Legal Journal of The Supreme Court Of Georgia And The Judges' Association Of Georgia).

8. Law Office of Simon Goldenberg, (2015). Frozen bank account in New York City, online:http://www.goldenbergfirm.com/Debt-Relief-Blog/2015/August/Exempt-Income-

Protection-Act-EIPA-.aspx.

9. Law Reform Commission of Nova Scotia, (2013). Enforcement of Civil Judgements: Exemption of Judgement Debtors' Income, online:http://www.lawreform.ns.ca/Downloads/Income\%20Exemption\%20-

\%20Discussion\%20Paper.pdf.

10. Minister of Labour, Health, and Social Affairs of Georgia), (2006). Order №225 / N of the Minister of Labor, Health and Social Affairs of Georgia.

11. National statistics office of Georgia, (2018). Subsistence Minimum, online:http://www.geostat.ge/?action=page\&p_id=178\&lang=geo.

12. Parliament of Georgia, (1999). Law of Georgia on Enforcement Proceedings.

13. Parliament of Georgia, (2010). Law of Georgia on State Property.

14. Parliament of Georgia, (2012). Law of Georgia on Payment Systems and Payment Services.

15. Raphael, D., (2007). Poverty and Policy in Canada: Implications for Health and Quality of Life (Toronto: Canadian Scholars Press) Low Income in Canada, supra note 8.

16. Reiter, M. Using Exemptions to Protect Property From Judgment Creditors, online: http://www.nolo.com/legal-encyclopedia/using-exemptions-protect-property-fromjudgment-creditors.html. 
Elisabedashvili, D., (2021)

Unenforceable Target Movable Property Under Enforcement

17. Strasbourg, European Court Of Human Rights, (1997). Judgement, Case of Hornsby v. Greece; Application no.18357/91; ECHR CaseLaw.

18. Tamara, M. Buckwold, R., Cuming, C., (2005). Final Report: Modernization Of Saskatchewan Money Judgment Enforcement Law (Saskatoon: University of Saskatchewan).

19. The Neighborhood Economic Development Advocacy, what is exempt from debt collection. Project online:http://www.neweconomynyc.org/what-is-exempt-from-debtcollection-2/.

20. The New Code of Civil Procedure of Luxembourg.

21. The MyLawyer Legal Team, online: https://www.mylawyer.co.uk/law-aA76076D76971/?A76076D76971 MyLawyer.co.uk.

22. Uitdehaag, J., (2013). Review of Enforcement system of Georgia. online:

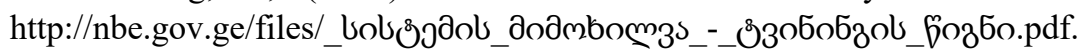

23. http://nbe.gov.ge/index.php?sec_id=155\&lang_id=ENG;

24. https://www.gov.uk/government/uploads/system/uploads/attachment_data/file/486166/5 3002 CoP Web.pdf.

25. https://www.justice.gouv.qc.ca/en/your-money-and-yourpossessions/seizure/unseizable-property-and-income/.

26. http://www.europe-eje.eu/en/fiche-thematique/note-3-attachment-tangible-movableproperty-professional-note- 2 . 